\title{
GREEN CERTIFICATIONS \\ WITHIN THE HOTEL INDUSTRY
}

\author{
Pernille Eskerod $^{5}$ \\ Jovana Đurić ${ }^{6}$
}

\begin{abstract}
A blooming hotel industry has the downside of an increased negative environmental impact. At the same time, many hotel guests and employees have become conscious of eco-friendliness and green practices. In addition, 2017 was by United Nations declared as the International Year of Sustainable Tourism for Development, with the emphasis on (among other elements) resource efficiency and environmental protection. A hotel that has green certification(s) promises more green services, products, and operations, and possesses thereby (potentially) important strategic assets, when it comes to attracting customers and employees. Many green certifications are offered within the hotel industry, such as for example Green Globe and Green Key. However, which certificate(s) to choose is a strategic choice for the hotel management. In this paper, we examine green certifications in order to determine similarities and differences among them. As part of the research, we analyze the usage of certificates in different regions (e.g. Southeast Europe). Even though many of the certifications are offered internationally, we identified clear differences in dissemination across region. In addition to region, the belonging to a hotel chain/brand seemed to highly influence the choice of certificate(s).
\end{abstract}

Key words: green certification, eco-friendliness, sustainability, hotel industry, strategic asset, strategic choice

\section{INTRODUCTION}

The hospitality industry is one of the world's largest and most important industries. It's more than evident that the extent of travels, international conferences and overnight stays have increased significantly and will continue to rise. The industry is not only recognized as a rapidly developing one, but also regarded as one of the most attractive businesses (Pizam and Shani, 2009).

Parallel to this, eco-friendly options are welcomed within the hospitality industry, where both hotels and airplanes opt for greener solutions. The hotel industry is often associated with large energy consumption, food waste, carbon emissions and lots of chemicals for washing and cleaning, but many hotels encounter an increasing number of hotel and conference guests that request more sustainable solutions from their accommodations.

With this background it seems evident that there is a big potential for the hotel industry to rethink business models and services aiming to reduce the consumption and waste,

\footnotetext{
${ }^{5}$ Full Professor, PhD, Webster Vienna Private University, Dept. of Business \& Management, Praterstraße 23, 1020 Vienna.

${ }^{6}$ Graduate Assistant, MBA, Webster Vienna Private University, Dept. of Business \& Management, Praterstraße 23, 1020 Vienna.
} 
and to increase the sustainability oriented experiences of the hotel guests. A new research project (Thomsen, 2017) shows that sustainability in the industry concerns more than saving kilowatt hours - it is as much about the combined care for the environment and for the guest.

Jensen claims that the development towards increased sustainability helps to increase profits, create more jobs and new business opportunities for the hotel industry (Thomsen, 2017). Among others, Graci and Dodds (2008) listed in detail the positive effects of going green, and these include gaining competitive advantage by being a leader in the sector, customer loyalty, employee retention, awards and recognition, increased brand value, risk management, and more. For this reason, thousands of hotels within hospitality industry's leading chains are now required to report their environmental impact to headquarters. According to Hasek (2013), more sustainability reporting is taking place at the corporate level, and the industry has been in agreement on how to calculate the carbon impact of hotel stays and meetings for almost a year now.

The year 2017 was by United Nations declared for International Year of Sustainable Tourism for Development with the emphasis on (among other elements) resource efficiency and environmental protection. There are many statements supporting the sustainability importance e.g. the World Tourism Organization (UNWTO) SecretaryGeneral, Dr. Rafai, indicated in 2015 that "[there is a] unique opportunity to advance the contribution of the tourism sector to the three pillars of sustainability - economic, social and environmental, while raising awareness of the true dimensions of a sector which is often undervalued" (UNWTO, 2015).

Our own interest in this research stems from the fact that we have observed a rapidly increasing interest within hotel management of many hotels to let the hotel certify (or by some certification bodies called 'be awarded') with green certificates. A hotel that has green certification(s) promises more green services, products, and operations, and possesses thereby (potentially) important strategic assets, when it comes to attracting customers and employees. However, many different green certifications are offered within the hotel industry, such as for example Green Globe and Green Key. The choice of which certificate(s) to select is a strategic choice for the hotel management. There are gaps in the literature when it comes to factors that cause hotel management to decide for a specific certificate, as well as challenges and practices when it comes to implementation of changes in services, products and operations.

As a first step to understand which factors that influence top managers' decisions to obtain a particular type of certification, we aimed to identify and classify different types of green certifications, and determine their similarities and differences. Further on, we investigated dissemination of the various certificates across regions. In addition, we wanted to identify whether the belonging to a hotel chain/brand would influence the choice of certificate(s).

In sum, the research aimed to answer following questions: 
$>$ What are the similarities and differences among global green certificates/certifications within the hotel industry?

$>$ What are the usage within the hotel industry in different regions (e.g. Southeast Europe) of different global green certificates?

$>$ How and to what extent does the belonging to a hotel chain/brand influence a given hotel's choice of certificate(s)?

The paper is structured as follows: First, the theoretical framework is presented. Hereafter, follows a section on research methodology. Next, a section on findings is presented and, finally, a conclusion, limitations and suggestions for further research are offered.

\section{LITERATURE REVIEW}

Weeden (2002) stated that in almost four decades numerous debates regarding the importance of global sustainable development have taken place. However, only since the 1990s the hospitality industry has been pursuing and adopting a significant number of green practices, as a result of fluctuating economic levels and a strong focus on customer service and satisfaction (Tzschentke, Kirk and Lynch, 2008). It appears that many travelers around the world now prefer so-called green hotels (Chan, 2013). Using the label "green hotel" has typically the purpose of playing a critical role in customers' decision-making processes and behavioral intentions (Prendergast and Man, 2002) and thereby attract potential customers (Pizam, 2009).

In order to understand the purpose of the concept of certification itself, Black and Crabtree (2007) suggested an extensive definition of certification i.e. "voluntary procedure that sets, assesses, monitors, and gives written assurance that a product, process, service, or management system conforms to specific requirements and norms. A certification/awarding body gives written assurance to the consumer and the industry in general. The outcome of certification is a certificate and usually the use of an ecolabel." (pg. 502)

Going Green has become the "it" topic of concern of the past several years and continues to gain transaction (Morris, 2004). According to Green Globe data, never before has the need for businesses to operate in an environmentally responsible manner been so evident. Many businesses nowadays seek to implement programs that demonstrate their commitment to sustainability as a major part of their Corporate Social Responsibility (CSR) policies, consequently constantly growing multi-billion dollar industries like sustainability related products, services and consulting.

Other studies also showed the beneficial effects of a green certificate as well as a constantly growing tendency for using it. For instance, Gagiolli (2015) stated that "the eco/green/environmentally friendly movement has become popular and shows no sign of stopping. Not only that guests are becoming more and more knowledgeable about green practices, but also they are creating certain expectations from the hotels in 
requesting them to possess the certificate. This being the case, their decision between booking one property over another depends on their eco-friendliness." Therefore, thirdparty certificates can help a hotel attract customers. Gagiolli (2015) supported his previous claims by adding that "obtaining a certification, especially one completed by a third-party auditor, will help confirm [the] team's effort, as well as convince guests [that the hotel's] eco-claims are valid". Similarly, Fukey and Issac (2014) discussed the benefits of green management, stating that many hotels profited from enhanced reputation of the firm and more worth customers, however the financial saving are the most essential reason when it comes to implementation decision. The reduction in cost for posting advertisements is beneficial, and the clear orientation of the hotel might increase employees' recognition of the workplace. So not only consumers can see the values of green certification, but also current and potential employees. According to Fukey and Issac (2014) "sustainability in business is the growth in lively processes which enable people to understand the potential to protect the Earth's existent support systems".

Sedmak (2017) pointed to another perspective of how green certificates can be valuable for the hotels. Green certifications represent a way to enhance consistency on the company level because: (1) it is guiding managers and employees, and (2) it is aligning expectations of customers and even suppliers (both existing and potential).

However, in order to achieve all the positive effects hotels are required to comply with a lot of strict rules and regulations, policies and procedures. Sometimes, it is hard to keep up with ongoing trends. For instance, most of the hotels instituted a changing towel policy, while the latest trend is to not replace them unless it is requested (Fukey and Issac, 2014). It is essential to provide special training to all the employees and offer them training programs about then environment. From the point of view of customers, Fukey and Issac (2014) considered that some guests are not willing to pay more to support a hotel's green initiative. This can be very risky for the hotels, as if they invest in the implementation, they might not only spend extra money but lose guests as well. The main reason can be low visibility of the certificate, which makes both employees and guests unaware (Bergin, 2010). An example supporting this claim would be 'low general environmental awareness' as well as 'lack of publicity'. (Tsai, Chan, Chou, Schultz, Heike and Yeung, 2003). After analyzing Island Shangri-La, the first hotel in Asia to obtain the ISO 14001 certification, the researchers identified that 'low employee involvement' is one of the major issue. After the employees realized that they were not directly affected by the green certification, which at the same time made them work even more, they tended to lose focus. The authors noticed that 'lack of government and industry support' can be some of the reasons when facing challenges with green management. 


\section{METHODOLOGY}

\section{TYPES OF DATA}

In summer 2017, secondary data for this study, consisting of websites and newspaper articles, was collected. The purpose of the data collection was to be able to compare dissemination of green certificates in numbers and geographical coverage. Moreover, the theoretical framework is based on research literature on green certifications, the hotel industry and sustainability. Searches have been undertaken through more of the academic databases and search engines, e.g. EBSCO databases, ProQuest, Scopus, and Google Scholar.

Based on the above mentioned data collection, primary data was also collected. A semistructured interview was used as the data gathering tool and the study was designed as a qualitative research. The interview was carried with the general manager of the only hotel in Serbia that has obtained the ISO 14001. The in-depth interview had the purpose to identify reasons of obtaining the certificate.

Some of the key questions were:

- What are the reasons for implementing Standard ISO 14001/Environmental Management System?

- Have you heard about any other green certifications within the hotel industry? If yes, what are in your opinion the potential benefits of other types of certifications? Have you heard about any other hotels which have green certifications?

- What influenced your decision to implement Standard ISO 14001 among all others globally offered green certifications?

\section{Selection of certificates and data analysis}

On a global scale, more than 140 green certification labels exist, e.g. Earth Check, Energy Star, Green Globe, Green Key, Green Key Globe, Green Tourism Active, ISO Standards with ISO 14001 being for Environmental Management, Travelife, Trip Advisor Greenleaders etc. To answer the given RQs within this study, comparison of three certifications was made. As we aimed for doing data collection in Serbia, due to convenience sampling, certificates used in Serbia influenced our choices for two of the chosen certificates. Our choices were: (1) Green Globe, which according to Gagiolli (2015) is one of the most popular/globally recognized green certifications; (2) Green Key, as Radisson Blu Old Mill hotel in Belgrade is announced to be the first hotel in Serbia with Green Key certificate; and (3) ISO 14001- Environmental Management, as this related to the in-depth interview with the general manager at Hotel Prag in Belgrade, Serbia. 
In order to determine differences and similarities across the three selected certificates, different aspects were selected: aim, process of certification, general characteristics, and criteria.

\section{FINDINGS}

\section{Dissemination of green certificates within the hotel industry}

Figure 1 offers an overview of the proportion of hotels with green certificate. It shows the density of environmental sustainability certified hotels per continent. Based on a study of $130000+$ hotels worldwide, 6.2\% were certified. It is interesting that Asia, as one of the leading business-growth areas of the world, has the lowest density, however, according to Koeppel (2017) $0.9 \%$ of all hotels in Asia with an environmental sustainability certification provides enough potential for improvement, should Asia ever feel the need to match or surpass the \% level of hotels in Europe or North America.

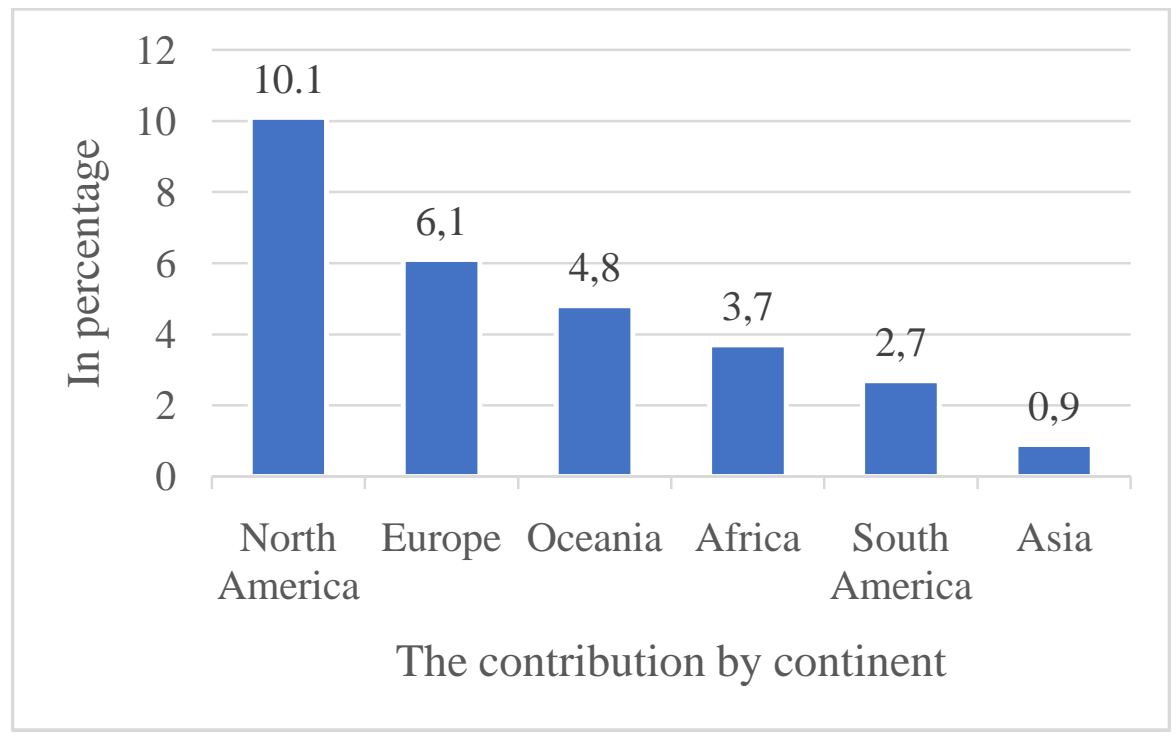

Fig. 1. Study of $130000+$ hotels worldwide

\section{Analysis of the selected green certificates}

The focus of Green Globe is on maximizing economic impact and minimizing social impact by investing in community development, local employment and entrepreneurs and fair trade, while Green Key aims to lower environmental footprints through sustainability management and to raise awareness of sustainability among staff and guests (International Tourism Partnership, 2016). Further, according to the Environmental Management System (2015), the aim of ISO 14001 is to provide 
organizations with a framework to protect the environment and respond to changing environmental conditions in balance with socio-economic needs.

Based on the description presented above, it is clear that Green Globe is the most general one out of the three, whereas Green Key is specific for hotels, and ISO 14001 is generally covering all industries, both manufacturing and services.

In order to understand, why top management at a hotel would choose a specific certificate, we asked the general manager of the only hotel in Belgrade that has implemented the ISO 14001, i.e. an Environmental Management System. The hotel is the first specialized business hotel in Serbia, and in 2017, it was awarded with the Certificate of Excellence by Trip Advisor based on hotel guest reviews. The general manager (Milas, 2017) stated that "ISO 14001 standard was implemented in 2014 with the desire of the hotel to do business according to the latest world standards which relate to the improvement of business through greater orientation and protection of the area in which we work and live." Further, they wanted to be ecologically responsible and to improve, additionally, their business and the outcomes of their work. The reason why ISO 14001 was selected among green certificate opportunities was that the hotel already had successfully implemented ISO 9001. This was due to the fact that the hotel owner had other business (outside the service sector), and they were also ISO certified. Therefore, it seemed like a natural choice for the hotel.

When identifying similarities and differences among the certification processes, it became clear from the certification schemes available online of all the three selected certificates (i.e. Green Globe, Green Key, and ISO 14001) that Green Globe has its own specific stages such as payment of membership, acquiring knowledge about the processes, and implementation of standards (in which minimum 50\% compliance rate with the standards is required). However, an independent third party audit on-site as well as a stage on getting the certificate issued is the same for all three certificates. However, Green Key uses another terminology as they don't call it 'to issue the certificate' but 'to award the Green Key'.

Green Key starts the process with a filling out an application form, where the client (i.e. the hotel management) has to self-assess to which degree the hotel complies with the Green Key criteria. Further, companies are asked to improve their compliance with criteria by $5 \%$ every year. The Green Key certificate is valid one year. A special characteristic for Green Key is that the awarded hotels (and other organizations) get visible on the website.

When it comes to ISO 14001, this certificate opens the process with enquiry, in a common process for the hotel (or other organization) and the certification body. Afterwards, the certification body has to confirm that the hotel (or other organization) can continue with the process. There are two stages of assessment, first as documentary review, and second an assessment on-site. In order for the certification and registration to take place, criteria have to be met. If they don't, they have to be improved. Annual surveillance is done, and renewal must happen every third year. 
In Table 1 the overview of different characteristics among the three certifications is presented. Obviously, Green Globe has a different level of assessment, however, this certificate has the lowest number of organizations certified.

Table 1. General characteristics of certifications

\begin{tabular}{|c|c|c|c|c|c|}
\hline $\begin{array}{l}\text { Certifyin } \\
\text { g body }\end{array}$ & $\begin{array}{l}\text { Different } \\
\text { levels of } \\
\text { assessments? }\end{array}$ & Cost & $\begin{array}{l}\text { Monitoring } \\
\text { and } \\
\text { Renewal }\end{array}$ & $\begin{array}{l}\# \\
\text { certified }\end{array}$ & $\begin{array}{l}\text { \# of } \\
\text { countries }\end{array}$ \\
\hline $\begin{array}{l}\text { Green } \\
\text { Globe }\end{array}$ & Yes & $\begin{array}{l}\text { EUR 620- } \\
4200 \\
\text { dependent } \\
\text { on size } \\
\text { plus } \\
\text { independe } \\
\text { nt audit } \\
\text { fees }\end{array}$ & $\begin{array}{l}\text { Annual } \\
\text { renewal } \\
\text { period, } \\
\text { standard is } \\
\text { updated and } \\
\text { reviewed } \\
\text { twice per } \\
\text { year }\end{array}$ & 508 & 90 \\
\hline $\begin{array}{c}\text { Green } \\
\text { Key } \\
\text { Foundati } \\
\text { on for } \\
\text { Environm } \\
\text { ental } \\
\text { Educatio } \\
\text { n (FEE) }\end{array}$ & No & $\begin{array}{c}\text { EUR } 1000 \\
\text { plus EUR } \\
500+ \\
\text { expenses } \\
\text { for audit }\end{array}$ & $\begin{array}{l}\text { Audits are } \\
\text { conducted } \\
\text { first and } \\
\text { second year } \\
\text { and then } \\
\text { every three } \\
\text { years. GK is } \\
\text { awarded for } \\
\text { one year at a } \\
\text { time }\end{array}$ & $\begin{array}{c}2400 \\
\text { hotels }\end{array}$ & $52-60$ \\
\hline $\begin{array}{c}\text { ISO } \\
14001 \\
\text { Various } \\
\text { certifying } \\
\text { bodies } \\
\text { accred. } \\
\text { by } \\
\text { national } \\
\text { accred. } \\
\text { bodies }\end{array}$ & No & $\begin{array}{c}\text { Depends } \\
\text { on audit } \\
\text { time and } \\
\text { audit time } \\
\text { depends } \\
\text { on client } \\
\text { size and } \\
\text { complexit } \\
\text { y } \\
\text { (EUR } \\
300-2000)\end{array}$ & $\begin{array}{l}\text { Annual } \\
\text { surveillance } \\
\text { minimum } \\
\text { per year and } \\
\text { renewal in } \\
\text { every three } \\
\text { years }\end{array}$ & $\begin{array}{c}1786 \\
\text { hotels } \\
\text { and } \\
\text { restauran } \\
\text { ts }\end{array}$ & 186 \\
\hline
\end{tabular}

Source: provided by the authors.

The last method to differentiate among the three certifications was by looking at their criteria. The findings can be seen in table 2. Please notice that 'to have indirect criteria' means that the criteria can only be assessed through other criteria. ISO 14001 has seven main requirements plus 36 others. As ISO 14001 is general standard, meaning that it is applicable for all services and manufacturing, implies that it cannot have specific requirements on hospitality elements as the two others have, especially Green Key. For instance, the difference is that Green Key requires food to be eco-labeled and organic (as well as the hotel is required to buy seasonal food, to consume less meat, and to decrease food waste), whereas the ISO 14001 standard just mention these elements 
indirectly by referring to protection of environment (e.g. ensuring that no contamination of water is taking place - and thereby securing the food quality). Green Globe (four main requirements plus 41 others) doesn't focus on food and beverage and outdoor activities in details. Health and safety criteria differentiate for Green Globe where it's covering well-being of its customers and staff, while for ISO 14001 the same criteria mean to manage emergency situations, such as a fire, and in that specific way to take care of guests and employees. For indoor activity, last but not least, Green Key (13 main and 128 others) has a special section related to non-smoking.

Table 2. Selected differences among the analyzed certifications

\begin{tabular}{|c|c|c|c|}
\hline Different Criteria & $\begin{array}{l}\text { Green } \\
\text { Globe }\end{array}$ & $\begin{array}{c}\text { Green } \\
\text { Key }\end{array}$ & ISO 14001 \\
\hline $\begin{array}{l}\text { Implement a Sustainability Management } \\
\text { System } \\
\text { Sustainability management system that } \\
\text { considers environmental, sociocultural, } \\
\text { quality, health, and safety issues }\end{array}$ & $\checkmark$ & $\checkmark$ & $\begin{array}{l}\text { ONLY } \\
\text { Environmental } \\
\quad \text { issues }\end{array}$ \\
\hline $\begin{array}{l}\text { Legal Compliance } \\
\text { In compliance with all relevant international } \\
\text { or local legislation and regulations (including, } \\
\text { among others, health, safety, labor, and } \\
\text { environmental aspects) }\end{array}$ & $\checkmark$ & $\checkmark$ & $\begin{array}{l}\text { ONLY with } \\
\text { Environmental } \\
\text { aspects }\end{array}$ \\
\hline $\begin{array}{l}\text { Local Zoning, Design and Construction } \\
\text { Design and Construction - Compliance with } \\
\text { Legal Requirements; Sustainable Design and } \\
\text { Construction of Buildings and Infrastructure - } \\
\text { New /Existing Buildings }\end{array}$ & $\checkmark$ & NO & $\checkmark$ \\
\hline $\begin{array}{l}\text { Health and Safety } \\
\text { Well-being of its customers, staff and local } \\
\text { community }\end{array}$ & $\checkmark$ & $\checkmark$ & indirectly \\
\hline $\begin{array}{l}\text { Social/Economic } \\
\text { Community Development, Local } \\
\text { Employment, Support Local Entrepreneurs, } \\
\text { Respect Local Communities, Exploitation, } \\
\text { Equitable Hiring, Employee Protection }\end{array}$ & $\checkmark$ & $\checkmark$ & NO \\
\hline $\begin{array}{l}\text { Fair Trade } \\
\text { Local and fair-trade services and goods are } \\
\text { purchased by the business, where available }\end{array}$ & $\checkmark$ & NO & NO \\
\hline Food and Beverage & NO & $\checkmark$ & indirectly \\
\hline Indoor Environment & NO & $\checkmark$ & $\mathrm{NO}$ \\
\hline
\end{tabular}

Source: provided by the authors.

The second research question concerned the number of certificates in different regions. The choices of regions were based on relevance and convenience sampling. We chose Northern Europe (as Green Key was founded in Denmark), Southeast Europe (as our interviewed general manager is from Serbia) and Central Europe (as we are situated in Austria). For Green Globe, we have in Figure 2 calculated number of members, whereas data for ISO 14001 is taken from their database, which is based on data 
provided by accredited certification bodies (please notice that the database is not fully accurate as non-accredited certification bodies exist, and some of them didn't deliver data to ISO). Obviously, Green Key is the most present in Northern Europe. This may be due to its origin there. When it comes to Southeast Europe, the majority of organizations with Green Key certificates is in Greece. The reason may be that Greece is a well-established tourist destination, and that Green Key is specialized for hotels. The results are presented in Table 3.

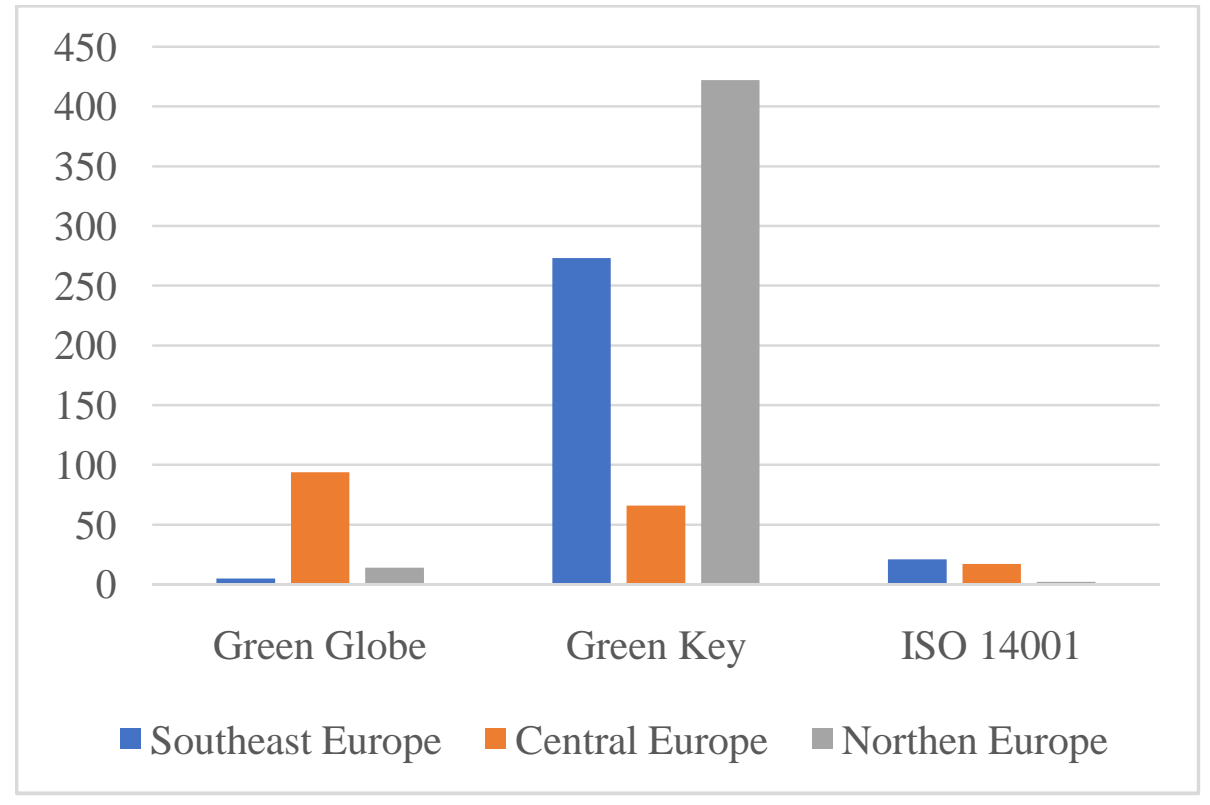

Fig. 2. The number of certificates in different regions

Table 3. The number of certificates in Southeast Europe per countries

\begin{tabular}{|l|c|c|c|c|c|c|c|c|}
\hline & AL & BIH & BU & CR & GR & MA & MO & RO \\
\hline $\begin{array}{l}\text { Green } \\
\text { Globe }\end{array}$ & 0 & 0 & 0 & 0 & 1 & 0 & 0 & 1 \\
\hline $\begin{array}{l}\text { Green } \\
\text { Key }\end{array}$ & 0 & 0 & 1 & 7 & 261 & 0 & 0 & 2 \\
\hline
\end{tabular}

Source: provided by the authors.

$\mathrm{AL}=$ Albania, $\mathrm{BIH}=$ Bosnia and Herzegovina, $\mathrm{BU}=$ Bulgaria, $\mathrm{CR}=$ Croatia,

$\mathrm{GR}=$ Greece, $\mathrm{MA}=$ Macedonia, $\mathrm{MO}=$ Montenegro, $\mathrm{RO}=$ Romania

In addition to region, the belonging to a hotel chain/brand seems to highly influence the choice of certificate(s). From the brief analysis presented below it can be seen that a hotel chain seems to be directly influencing the decision concerning the selection of a specific certification. For example, all Radisson Blu hotels must have Green Key, as this is policy of the company. However, in UK, the green certificate, Green Tourism, exists, so therefore the Radisson Hotels in UK tend to have this certificate as well in order to comply with the regional requirements/expectations in order to be competitive on the UK market. In the same line, we identified local eco-labels at other Radisson 
hotels (e.g. Radisson Blu Resort Malta, St. Julian's. Maltese Eco-label) to supplement Green Key.

Therefore, when a hotel is not influenced by a chain (e.g. the Radisson Blu chain), top management can make its own decision and be influenced by other factors, as can be seen in Table 4 below.

Table 4. Brief analysis on the two hotels with green certificates in Serbia

\begin{tabular}{|l|l|l|l|l|l|}
\hline $\begin{array}{l}\text { Name of } \\
\text { the hotel }\end{array}$ & $\begin{array}{l}\text { Certifi- } \\
\text { cation } \\
\text { type }\end{array}$ & $\begin{array}{l}\text { Type of the } \\
\text { hotel } \\
\text { belonging }\end{array}$ & $\begin{array}{l}\text { Influence } \\
\text { of hotel } \\
\text { chain on } \\
\text { certifica- } \\
\text { tion's } \\
\text { choice }\end{array}$ & $\begin{array}{l}\text { Influence } \\
\text { of hotel } \\
\text { region on } \\
\text { certifica- } \\
\text { tion's } \\
\text { choice }\end{array}$ & $\begin{array}{l}\text { Other } \\
\text { reason for } \\
\text { choosing } \\
\text { certain } \\
\text { certification }\end{array}$ \\
\hline $\begin{array}{l}\text { Hotel } \\
\text { Prag, } \\
\text { Belgrade }\end{array}$ & $\begin{array}{c}\text { ISO } \\
14001\end{array}$ & $\begin{array}{c}\text { Privately } \\
\text { owned } \\
\text { company, } \\
\text { independent }\end{array}$ & No & No & $\begin{array}{c}\text { ISO 9001 } \\
\text { Standard } \\
\text { was already } \\
\text { implemented } \\
\text { the existence } \\
\text { of some of } \\
\text { the ISO } \\
\text { Standards } \\
\text { required }\end{array}$ \\
\hline $\begin{array}{l}\text { Radisson } \\
\text { Blu Old } \\
\text { Mill, } \\
\text { Belgrade }\end{array}$ & $\begin{array}{l}\text { Green } \\
\text { Key }\end{array}$ & Hotel chain & Yes & Yes & No \\
\hline
\end{tabular}

Source: provided by the authors.

\section{CONCLUSION, LIMITATION AND FURTHER RESEARCH}

Existing research points to the positive effects as well as challenges of obtaining green certifications. Our contribution is that we have identified many differences across certifications, when it comes to different aspects like aim, process of certification, general characteristics and criteria. Further on, our research points to the likelihood that already received certifications (like ISO), the region (which could be due to competitors' actions when it comes to green certification) and/or the chain, the hotel belongs to (if it belongs to a chain) will heavily influence decision makers when considering to apply for a green certificate.

The limitations of this research are: (1) it focuses only three certifications only; and (2) only one interview was conducted.

In future studies, we would suggest comparative studies related to green certification usage in different counties. Moreover, our own research could be repeated with interviews in more hotels. 
We believe that it would be interesting to examining how voluntary certifications (like green certificates) are associated with corporate branding. Further, we also think that there is a research gap when it comes to insights in the implementation and operation of the green certificates.

\section{REFERENCES}

1. Bergin, M. (2010). Manage your environmental costs. Hotel \& Catering Review, 33-35.

2. Black, R. \& Crabtree, A. (Eds.) (2007). Quality Assurance and Certification in Ecotourism. Wallingford: Cabi Publishing.

3. Chan, E.S.W. (2013). Gap analysis of green hotel marketing. International Journal of Contemporary Hospitality Management, 25(7), 1017-1048.

4. Environmental management system - Requirements [Brochure]. (2015). Belgrade, Serbia: Institute for Standardization of Serbia.

5. Gagiolli, A. (2015, August). Eco-Friendly hotel certifications overview. Retrieved from https://www.cloudbeds.com/articles/eco-friendly-hotelcertifications-overview/

6. Graci, S., \& Dodds, R. (2008). Why go green? The business case for environmental commitment in the Canadian hotel industry. Anatolia, 19(2), 251-270.

7. Hasek, G. (2013, May). 2013 - The greenest year yet for our industry? Green Lodging News. Retrieved from: http://www.greenlodgingnews.com/2013-thegreenest-year-yet-for-our-industry/

8. International Tourism Partnership. (2016, July). Know How Guide: Sustainable Hotel Certification Schemes. Retrieved from: http://www.scpclearinghouse.org/sites/default/files/khg certifications.pdf

9. Koeppel, D. (2017, February). Awards, standards and certification - what's the difference? Retrieved from http://danielkoeppelandassociates.com/sustainability/how-sustainabilty-helpsincrease-the-bottom-line/awards-standards-and-certification-whats-thedifference

10. Milas, B. (2017, September 6). Written interview. General Manager, Hotel Prag, Serbia.

11. Morris, N. (2004). Sustainability: What is it? Power Engineer. Academic Search Power Engineer, 18 (5), 11-11.

12. Pizam, A., \& Shani, A. (2009). The nature of the hospitality industry: present and future managers' perspectives. Anatolia, 20(1), 134-150.

13. Pizam, A. (2009). Green hotels: a fad, ploy or fact of life? International Journal of Hospitality Management, 28(1), 1. 
14. Prendergast, G. and Man, H.W. (2002). The influence of store image on store loyalty in Hong Kong's quick service restaurant industry. Journal of Foodservice Business Research, 5(1), 45-59.

15. Sedmak, G. (2017, September). Keynote Speech presented at the International Tourism and Hospitality Management Conference, Belgrade, Serbia.

16. Thomsen, F. B. (2017, February). Implementation of green practices is valuable for Danish hotels. Retrieved from:

http://www.greenkey.global/stories-news-1/2017/2/3/implementation-of-greenpractices-is-valuable-for-danish-hotels

17. Tsai, T., Chan, L. C. C., Chou, K. H. Y., Schultz, M., Heike, F., \& Yeung, K. Y. L. (2003). Island Shangri-La's Environmental Management System: A Long Way to Go! Asian case research journal, 7(02), 173-194.

18. Tzschentke, N. A., Kirk, D., \& Lynch, P. A. (2008). Going green: Decisional factors in small hospitality operations. International Journal of Hospitality Management, 27(1), 126-133.

19. UNWTO. (2015, December). United Nations declares 2017 as the International Year of Sustainable Tourism for Development [Press Release]. Retrieved from http://media.unwto.org/press-release/2015-12-07/unitednations-declares-2017-international-year-sustainable-tourism-develop

20. Weeden, C. (2002). Ethical tourism: An opportunity for competitive advantage? Journal of Vacation Marketing, 8(2), 141-153.

21. http://pathwaytosustainability.org/green-globe-international-inc/ 